\title{
Mechanisms for ensuring the environmental safety of tourist destinations
}

\author{
Olena Pobihun ${ }^{1, *}$, Yaroslava Korobeinykova ${ }^{1}$, Olha Nykodiuk$^{1}$, and Andriy Melnyk ${ }^{1}$ \\ ${ }^{1}$ State Institution "Ivano-Frankivsk National Technical University of Oil and Gas", Institute of Natural Sciences and Tourism, \\ Department of Tourism, 15 Karpatska str., Ivano-Frankivsk, 79019, Ukraine
}

\begin{abstract}
Modern tourism is a sector of the economy that is developing very fast, for the last 10 years the growth was $25 \%$. According to UNEP and the WTO, tourism is seen as a growing sector in contrast to the manufacturing sector. According to experts, the growth rate of the tourism industry will remain high, although global and regional structures of tourism change over the years (in recent years due to terrorism, the development of various diseases, natural disasters, pandemics, etc.). In 2019, about 1,500 million international trips were made. The same data indicate that the growth of tourism is due to developing countries. In countries with weak regulation of the market economy, tourism development can become a real threat to the quality of the environment. Therefore, the further development of tourism, in general, is possible only through its greening and finding a balance between economic and social development, taking into account environmental factors.
\end{abstract}

\section{Introduction}

Current scientific publications in this field relate mainly to the formation of concepts, conceptual framework and general principles of sustainable tourism development. Tourism can be defined as a system of balanced tourism, which deals with the growth of the developing market due to the growing interest in the natural environment. With the growth of tourist services, the expansion of tourist infrastructure, the ecological situation in the territories in connection with their recreational use can reach a threatening state. However, the literature on balance often contains broad definitions based on an immeasurable ideal state, which can be governed by a number of basic principles, which are often vague and contradictory.

The issue of sustainable tourism development is relevant on the agenda of world meetings on environmental protection and tourism development in recent years.. In Ukraine was developed "Strategy for sustainable development of tourism and resorts" [1,2]. Scientific publications of recent years are devoted to substantiation of scientific bases of balanced development of tourism, separate aspects of maintenance of balanced development of tourist regions [3-5]. The components of sustainable tourism development are identified, the main environmental problems associated with the expansion of tourism, the features of environmental aspects of tourism development in mountain tourist destinations. Ensuring the sustainable development of recreational areas is carried out through the establishment and maintenance of a balance between the preservation of natural, historical and cultural resources, economic interests and social needs and the development of tourism.

Basic concepts and principles of sustainable tourism development, characterized by environmental, economic and social aspects of its development were outlined by us [6]. A practically unresolved problem in the development of the concept of sustainable tourism development is the development and practical implementation of tools (means) to implement the principles of balance in practice. Therefore, our main goal is to analyze these issues.

\section{Statement of the main material}

Tourism is a constant and quite intensive user of natural resources. At the same time, the tourism industry not only makes extensive use of natural resources, but also pollutes the environment. On the other hand, the favorable ecological condition of tourist areas is considered by tourists as a separate tourist resource, which is in steady demand, especially in the period of recovery from the pandemic and the need for recovery in environmentally friendly living conditions. Negative aspects of the impact of mass tourism on the environment and tourist resources were noted in the 70's in foreign studies. The rapid development of the tourism industry has led to a high concentration of production - hotel chains appear, the construction of tourist centers begins. Investing significant funds in the development of tourism, large capital requires maximum profit in the shortest possible time. The rapid development of tourism is supported in order to ensure economic development and increase the level of currency inflows. For example, the development

\footnotetext{
*Corresponding author: alenapobigun@gmail.com
} 
of tourism in the Mediterranean region since the 1960s and until recently illustrates the significant amounts of ecological degradation of geosystems that may occur as a result of large-scale tourism development [7]. The natural landscape and the local population were perceived only as a means to an end. Not surprisingly, the result of the growth of mass unregulated visits to recreational natural complexes was an extremely negative impact on them, as well as on the local socio-cultural environment. The wild originality of unique natural places, as well as local economies and cultural values of tourist destinations are under threat. Examples of the negative consequences that accompany excessive visits by tourists to recreational natural areas are known today in large numbers. The most convincing examples are the degradation of a number of major US national parks, the Geyser Valley in Kamchatka, recreational areas in the Alps, the accumulation of debris on Everest in Nepal (Fig.1) and the Inca Trail in South America [8]. In 1983, the famous Austrian journalist L. Lukshanderl published his book "Save the Alps! Garden on the roof of Europe in danger ", in which in popular science form outlined the main environmental problems of tourism development [9]. The degradation of natural areas for tourism development has necessitated the introduction of systematic nature protection measures in tourism practice. Since the tourism industry is mainly seasonal, the number of tourists in a given area at the height of the season is several times higher than in the "dead season". This situation leads to uneven anthropogenic pressure on ecosystems. The study of the consequences of tourism activities for ecosystems and the introduction of environmental management technologies in the practice of recreational nature has emerged as the most pressing problem of further development of tourism. However, the definition of objects of environmental research remains controversial and ambiguous.

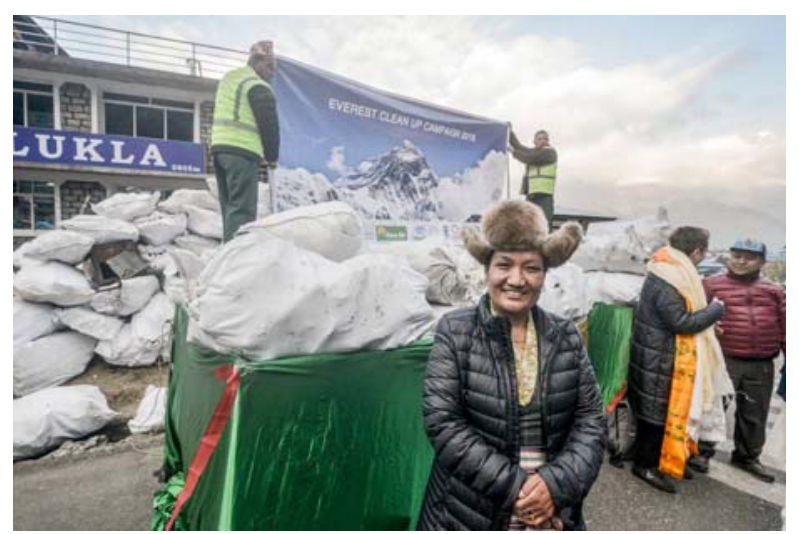

Fig. 1. Campaign to clean up and remove rubbish from Everest left by tourists and climbers on the world's highest mountain, Nepal, March 17, 2018, photo: EPA-EFE / BIKAS KARKI.

Today, anthropogenic impact on ecosystems is characteristic of all sectors of the tourism industry and types of tourism and is observed in the vast majority of tourist destinations. It is tourist destinations of different hierarchical levels that are the objects of ecological research and are considered as natural-technogenic systems from the point of view of ecological research. The term "tourist destination" in the practice of tourism research appeared not so long ago. In foreign literature on the theory and practice of tourism, this term has been used for several decades. The most famous works of Leiper, Cooper, Fletcher, which give the definition of tourist destinations and their systematization. In a more general form, the tourist destination is the territory of arrival and location of tourists. According to N. Leiper, a tourist destination is a place of arrival of tourists and is considered as a geographical category [10].

The World Tourism Organization defines a tourist destination as follows: «A destination is a physical space in which a tourist stays for at least 24 hours. It contains tourist products such as services and attractions, as well as tourist resources within at least one day of stay. This space has physical and administrative boundaries that determine the form of its management, image and reputation, which affect its competitiveness in the tourism market». It should be noted the thorough works of domestic scientists in this field $\mathrm{T}$. Tkachenko, $\mathrm{L}$. Dyadechko, A. Holovchan, S. Melnychenko, Y. Leontieva, Y. Maltseva and others [11-15]. In the work of Matrishenko N.S. tourist destination is presented as a "center (territory) with all kinds of amenities, facilities and services to meet all the needs of tourists". According to him, now the destination is a geographical area that has certain boundaries, which can attract and meet the needs of a wide range of tourists [16].

In most modern interpretations, a tourist destination is considered as an economic and socio-economic system, as an object of integrated management. To do this, the tourist destination combines all the elements for the provision of tourist services. A tourist destination arises precisely as a geographical unit, as a territory, route or localized object that is a place of tourist interest ("tourist destination"), other components, such as elements of tourist infrastructure, should be considered "superstructure", gradually revealing the essence of a tourist destination in the course of evolutionary development. Thus, a tourist destination is defined as an economic and geographical category, where the basis of its operation is a territorial resource with possible problems of using nature, including environmental. Despite the rather broad and detailed interpretation of the concept of a tourist destination, the ecological aspects of its optimal functioning are ignored. A tourist destination, in the context of its balanced development, is a naturaltechnogenic system of tourist-recreational type, due to the specialization of tourist activity and certain factors of environmental impact that will determine its ecological safety. The structuring of natural and man-made systems of tourist destinations, their hierarchy, approaches to the systematic study of environmental aspects of their activities require further research.

At present, a scientific direction on the environmental safety of natural and natural-man-made systems of different levels has been formed. In the works of A.B. Kachynski, G.I. Rudko, S.V. Hoshovsky, V.M. Shmandiy, S.V. Rudenko, L.E. Shkitsa, B.M. Danylyshyn, V.O. Kosovtsev, Binko I.F., V.M. Shestopalov, M.S. Malovany etc. scientific and methodological approaches to ensure environmental 
safety in natural and man-made natural systems, as well as applied aspects of environmental safety [17-25]. Methodological and applied mechanisms of researches of technogenic changed ecosystems and maintenance of their ecological safety are developed [26-35]. On the territory of Ukraine there are large oil fields - explored, abandoned, some and unexplored. They also pose a risk of contamination of soils, water resources, air, which in turn impairs the tourist attractiveness of tourist destinations. Therefore, the latest technological and economic methods of regulating this activity should be used to reduce the impact on the environment $[36,37]$.

Less studied are the issues of environmental safety research and management in the conditions of mancaused load, which is not pronounced extreme, for example, the territories of tourist destinations. The analysis of certain aspects of environmental safety in the development of the tourism industry, as part of its balanced development, engaged in A.P. Hunger, N.V. Korzh, V.I. Kutsenko, T.L. Mironova, V.V. Sharko and others [38-41]. Some scientists consider the objects of such research to be elements of infrastructure and their impact on the environment, some consider determining the ecological boundaries of activities by calculating the recreational load on the territory. Analysis of publications in recent years has identified the main impacts of tourism on the environment. Tourism can have a negative impact on local energy resources, water resources, land resources, the use of which in tourism is constantly increasing.

\section{The research results}

With the growth of the tourism industry, there is a direct impact on natural landscapes and changes in primary landscapes as a result of the construction of tourism infrastructure. Intensive construction of accommodation facilities, roads, airports, use of land resources as a building material for housing infrastructure leads to degradation and depletion of landscape elements, its radical change. The problem of traffic jams, insufficient number of parking spaces, a sharp increase in the cost of land have become a reality in such areas. Intensive tourism development absorbs land resources and has led to the loss of agricultural land and natural landscapes. Territories are becoming highly urbanized. The construction of marinas, breakwaters and other structures leads to changes in natural landscapes - changes in the direction and strength of currents, then - changes in the coastline and coastal erosion, which leads to the loss of beach areas. Although the pace of construction of tourist infrastructure in Ukraine is not so high, but the problems of degradation of the Black Sea coast, sampling of sand from beaches, destruction of large forests in the construction of tourist infrastructure in mountainous areas of Ukraine are very pressing environmental issues. Thus, the tourist complex "Bukovel" according to the original project occupies a considerable area: the total area for the construction of cottages and hotels: two-storey cottages 100 hectares; hotels - 50 hectares, infrastructure of cottage - hotel complex (25-30\% of housing) - 45 hectares; total area for ski slopes and lifts (at the rate of 30 to $50 \mathrm{~m}$ width of one track) - approximately 300 hectares; total area for water reservoirs intended for snowmaking of 60 ha of ski slopes (three reservoirs with a depth of $3 \mathrm{~m}$ and a volume of 16 thousand $\mathrm{m}^{3}$ each) -0.55 ha. The tourist complex is constantly expanding, now occupying about 822 hectares, with a total length of ski slopes of more than $100 \mathrm{~km}$ (Fig. 2) [42].

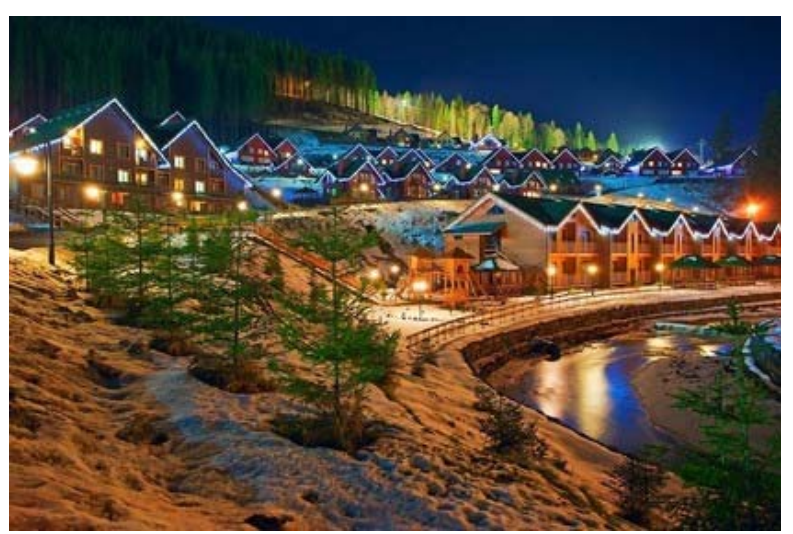

Fig. 2. Tourist complex "Bukovel", p. Polyanitsa.

Intensive use of water resources and their pollution is also an environmental problem of tourist destinations. Construction of hotel and entertainment complexes often leads to overload of sewer systems. Wastewater treatment plants do not always cope with large volumes of wastewater in the height of the season, wastewater is sometimes discharged into seas and lakes without treatment, negatively affecting not only flora and fauna, but also the quality of the recreational environment for vacationers.

In Ukraine, the problem of pollution of water and land resources from tourist facilities is very acute. Tourist infrastructure, especially on the coasts, is developing chaotically, without proper environmental justification. It is not uncommon for direct discharges of wastewater into the sea, the construction of hotel complexes on beaches, within water protection zones, the development of unorganized tourism on the coast in the absence of sanitary facilities. Thus, the tourist complex "Bukovel" uses groundwater for domestic and drinking water supply, production of artificial snow, which leads to the extraction of significant amounts of water from underground horizons. Sewage from small hotels and rural estates remains a problem, as the vast majority of tourist destinations do not have centralized drainage systems. Sample observations of water use in Ivano-Frankivsk region showed that the average water consumption in rural estates is about 100 liters per day, uncategorized hotels - from 120 to 300 liters per day, in star hotels - more than 300 liters per day, depending on the offers of hotels for health and recreational services (availability of swimming pools, spa treatments, etc.). These results fully confirmed the WTO data on the water consumption of hospitals: with increasing category and comfort, these figures are growing. Moreover, the indicators of water use by tourists in accommodation establishments are higher than their average consumption by the population of tourist destinations. According to approximate 
calculations, with an average tourist stay of 4 days, the volume of tourist water use in the region is about 2.4 million $\mathrm{m}^{3}$.

Using of energy. Hotels and other tourist infrastructure use a lot more electricity than the average local. Thus, according to EU energy saving experts, the use of energy per $1 \mathrm{~m}^{2}$ in a non-star hotel is $157 \mathrm{kWh}$, in a four-star hotel - already $380 \mathrm{kWh}$ [43]. That is, with increasing comfort of the means of placing energy consumption increases. In many areas of tourism development, the energy system is not designed for such significant energy consumption. Thus, a significant reconstruction of the local energy supply system has been carried out in the area of the Bukovel tourist complex for uninterrupted power supply. The issue of energy supply in the tourism sector can be solved through the use of renewable energy sources, scientists have made such a justification [44-46] (Fig.3). For energy companies that are within the impact on environmental facilities, recreational areas, scientists have proposed technical solutions and new methods and means of measuring the volume of oxygen to improve the accuracy of determining the ratio of excess air during fuel combustion [47]. Also, great attention should be paid to the training of specialists in the field of energy, as well as the use of modern methods and approaches to training, the use of GIS technologies [48, 49].

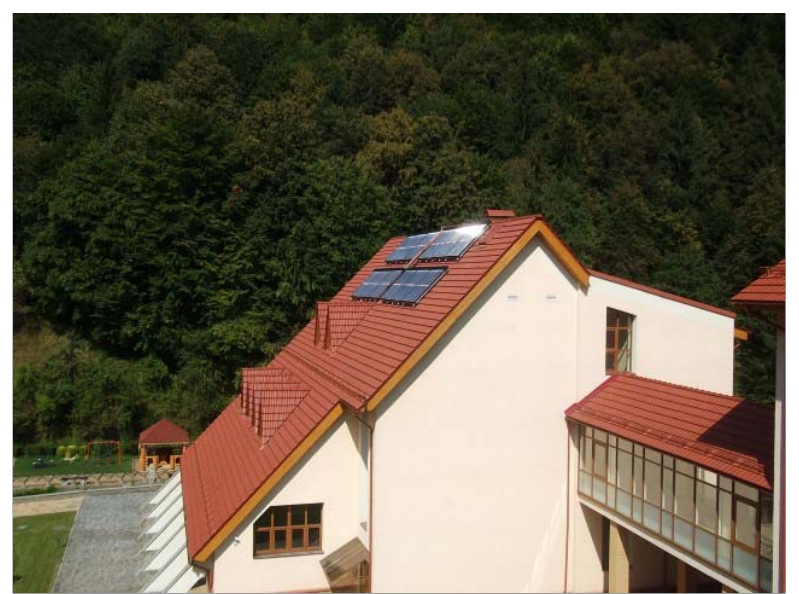

Fig. 3. Vacuum solar collectors are used to heat water in the sanatorium "Carpathian Stars", Yaremche.

Air pollution and the problem of solid waste are also environmental problems of tourist destinations. The growth of the tourism industry leads to a high concentration of tourists and the corresponding infrastructure. This leads to air pollution from road, rail and air transport. For example, $60 \%$ of all air traffic in the world is directly related to tourism, so tourism is also "responsible" for air pollution. Noise pollution from transport, and sometimes from tourists themselves, is another important problem. On the other hand - air pollution is also a problem for the organizers of tourist activities, because the tourist expects from the rest areas, first of all, clean air and the absence of noise discomfort. Sources of air pollution are usually vehicles (cars) (Fig. 4). So, in the tourist complex "Bukovel" in a peak season arrival of about 900 units of motor transport is fixed daily. Atmospheric air pollution by vehicles leads to the accumulation of pollutants in soils and their subsequent migration along the food chain. In the scientific works of various authors there is work to determine the risk assessment for the population as a result of air pollution $[50,51]$.

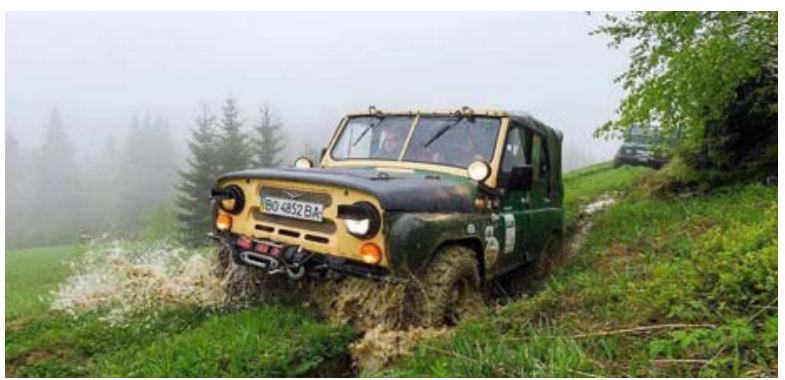

Fig. 4. Dangerous car tours in the Carpathians.

For many tourist destinations there is a problem of solid waste management of tourism enterprises: the amount of waste is growing faster than the possibility of their disposal. The problem is complicated by the need to transport solid waste over long distances. Scientists have modeled the formation of solid waste within the IvanoFrankivsk region and justified the need to take into account the increased flows of tourists in the development of roadmaps for waste management in tourist destinations [52-54].

Thus, the environmental impact of tourist destinations increases with the development of the industry and there is a need to systematize the mechanisms for implementing environmental safety within the territories of tourism. We have analyzed and summarized information on the application of various measures and mechanisms to ensure the environmental safety of natural and man-made systems. We propose to classify them into regulatory, economic, controlling and voluntary mechanisms for ensuring the environmental safety of tourist destinations (Fig. 5).

Regulatory tools make it possible to reduce the impact on destinations from tourism by regulating the capacity of the territory, setting limits and limits on the activities of enterprises providing services to tourists, through environmental impact assessment of tourism, environmental monitoring and sustainability of territories. Regulation of the number of tourists on the territory is an important factor in the balanced development of tourist areas. Territorial communities and environmental structures in the territories of which tourism is developing can regulate the flow of tourists, offering alternative routes and optimizing tourist flows quantitatively. This factor must be taken into account when planning recreational settlements. The system of monitoring potential impacts on the territory is a necessary tool for monitoring the environmental parameters of pollution and indicators - indicators of balanced development of territories. In the system of observations at the first stage it is necessary to carry out inventory of the basic recreational resources, definition of objects of monitoring, a choice of estimation parameters, a mode of supervision. 


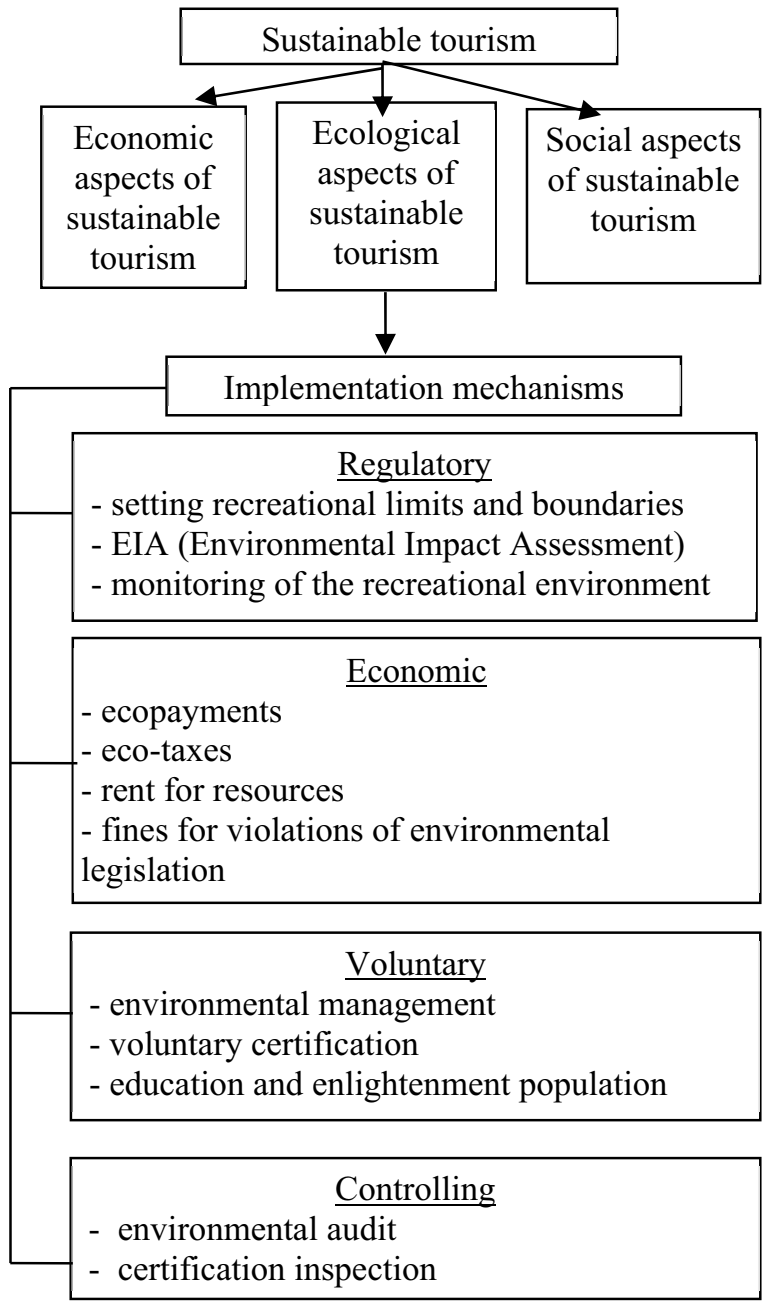

Fig. 5. Mechanisms for ensuring the environmental safety of tourist destinations.

In the process of forecasting the state of the recreational environment determine possible negative trends in its development in various aspects, such as increasing the functional hazard of tourist and recreational equipment, deteriorating ecological condition of tourist destinations, reducing the attractiveness of tourist facilities, etc. Together, these processes can lead to the degradation of tourist destinations, reduce the flow of tourists. The results of forecasting can be a factual basis for the development of measures to manage the recreational environment. Managment is considered as practical activities in the field of regulation of recreational systems in accordance with the needs of the economy and tourists on the basis of objective laws of nature and socioeconomic development. The success of management measures is determined by the effective functioning of tourist destinations, namely the positive dynamics of the tourism industry and related industries, the optimal load of the recreational environment by vacationers, favorable environmental conditions of tourist destinations and safe use of recreational resources. Thus, this monitoring system fits into the traditional framework of monitoring concepts.

Setting limits on the environmental impact of tourism facilities is seen as an effective mechanism for ensuring the environmental safety of tourist destinations.
Compliance with environmental standards is the most important component of the mechanisms for implementing the principles of balanced tourism. Environmental standards are uniform and mandatory for all objects of this type and level of the system of norms and requirements for the environment.

The main economic mechanisms for ensuring the environmental safety of tourist destinations are financial incentives, monetary rewards, financial support for projects aimed at implementing the principles of balanced tourism, balanced tax policy and procedures for subsidizing balanced tourism projects. Tourist eco-taxes and payments are taxes paid by tourists for the ecological needs of territories. This practice is common in the most environmentally vulnerable tourist destinations in the world.

The main control mechanisms for ensuring the environmental safety of tourist destinations are to implement actions to control the activities of tourism entities in the field of environmental safety of tourist destinations. Conducting an environmental audit is an important management tool, which is a systematic, documented periodic and objective assessment of the organization's compliance with the management system, equipment for environmental safety and environmental policy of the enterprise.

Certification is a process of assessment and monitoring that confirms in writing that a business, product, process, service or management system meets certain requirements. This process is important in enterprises of different directions [55]. In the practice of environmental certification of accommodation establishments, there are about 30 eco-labeling systems. In Ukraine, a method of voluntary environmental certification of rural tourism homes "Zelena sadyba" has been developed.

The main additional mechanisms to ensure the environmental safety of tourist destinations include the introduction of environmental management in the structure of general management, marketing and demarketing, training of tourists and locals. Professional environmental management in the tourism industry, especially hospitality, such as energy saving measures, reducing water consumption, waste minimization, the use of environmentally friendly materials can reduce the environmental impact of tourism development. Training of tourists and locals can take place various forms. This is the implementation of educational programs, social advertising, printed materials, volunteer work, etc. This activity becomes especially relevant in the process of organizing ecological tours, visiting natural, nature reserves.

\section{Conclusions}

Thus, the main problem in the development of the concept of sustainable development of tourism is the development and practical implementation of tools (means) to implement the principles of balance in practice. Ensuring the environmental safety of tourist destinations is one of the main priorities for sustainable tourism development. 
Favorable environmental situation within tourist destinations is considered by tourism experts as an equivalent factor in the development of the tourism industry. Mechanisms for ensuring the ecological safety of tourist destinations are proposed, the use of which will allow to implement the ecological component of sustainable tourism development. Research on the effects of man-made load on the ecosystems of tourist destinations is a promising scientific field in the field of environmental safety.

\section{References}

1. UN WTO: Tourism Industry (2020), https://www.reportlinker.com/report/search?dates=1y \&keywords=Tourism $\% 20$ Industry $\% 202019 \&$ mode $=p$ ublic. Accessed 15 June 2020.

2. Stratehiya staloho rozvytku turyzmu $i$ kurortiv $v$ Ukrayini (Strategy of sustainable development of tourism and resorts in Ukraine), (Government portal, 2017), https://www.kmu.gov.ua/npas/ 249826501. Accessed 15 June 2017.

3. O.A. Vorobyov, I.M. Dyshlovsky, S.K. Kharichkov, Problemy pryrodokorystuvannya ta staloho rozvytku $v$ rekreatsiyno-turystychniy sferi (Problems of nature management and sustainable development in the recreational and tourist sphere). (ShPREED NAN of Ukraine, Odessa, 2009).

4. I.V. Kuchynska. Tourism in the context of the global environmental crisis: current challenges and prospects for development in Proceedings of the international scientific-practical conference "Strategy for tourism development in the 21st century. in the context of solving today's global problems" (LIET, Lviv , 28.05.2014), pp.291-301.

5. T. Tkachenko, Stalyy rozvytok turyzmu: teoriya, metodolohiya, realiyi biznesu (Sustainable development of tourism: theory, methodology, business realities). (KNTU, Kiev, 2009).

6. Y.S. Korobeynikova, Stratehiya staloho rozvytku turyzmu (Strategy of sustainable tourism development). (IFNTUNG, Ivano-Frankivsk, 2016).

7. B. Sli, Intehratsiya u haluzevu polityku pytan' zberezhennya biolohichnoho ta landshaftnoho riznomanittya: rozvytok ekolohichnoho turyzmu $v$ Ukrayini (Integration into sectoral policy of biodiversity and landscape diversity: development of ecological tourism in Ukraine). Zberezhennya i monitorynh biolohichnoho ta landshaftnoho riznomanittya v Ukrayini (Kyiv, 2000), pp. 59-67.

8. P. M. Godde, M. F. Price, and F. M. Zimmerman, editors, Tourism and Development in Mountain Regions (CABI Pub, Wallingford, Oxon, UK; New York, NY, USA, 2000).

9. L. Lukschanderl, Rettet Die Alpen: Europas Dachgarten in Bedrängnis (Orac, Wien, 1983).
10. N. Leiper, Tourism Management, 3rd ed (Pearson Hospitality Press, Sydney, 2004).

11. A.I. Golovchan, Teoretyko-metodolohichni pidkhody do vyznachennya sutnosti turystychnykh destynatsiy ta upravlinnya nymy (Theoretical and methodological approaches to defining the essence of tourist destinations and their management), Zbirnyk naukovykh prats' "Torhivlya ta rynok Ukrayiny" 27, 157-161 (2009). http://www.nbuv. gov.ua/2009_27/24.pdf. Accessed 20 December 2019.

12. L.P. Dyadechko, Ekonomika turystychnoho biznesu (Economics of tourism business) (Donetsk, DonDUET, 2006).

13. S.V. Melnichenko, Upravlins'kyy mekhanizm rozvytku turystychnoyi destynatsiyi (Management mechanism for the development of a tourist destination), Ekonomika. Upravlinnya. Innovatsiyi 2(6) (2011). http://infotour.in.ua/melnychenko5. htm. Accessed 25 December 2019

14. Y.Y. Leontyeva, O.A. Timoshchenkova, Regional'naya turisticheskaya destinatsiya $i$ yeye sotsial'no-ekonomicheskoye razvitiye (Regional tourist destination and its socio-economic development), $\begin{array}{llll}\text { Biznes-inform } & \mathbf{6}, & 165-170 & \text { (2013). }\end{array}$ http://nbuv.gov.ua/UJRN/binf_2013_6_28.Accessed 17 July 2020.

15. N.A. Goncharova, Podkhody k opredeleniyu kontsepta «turistskaya destinatsiya» v nauchnom diskurse (Approaches to defining the concept of "tourist destination" in scientific discourse), Vektory blagopoluchiya: ekonomika i sotsium, 2(17), 100-115 (2015) https://jwt.su/journal/issue/ view/25. Accessed 12 July 2020.

16. N.S. Matryshenko, Klasternyy podkhod $k$ prostranstvennomu razvitiyu turistskikh destinatsiy regiona (na primere Primorskogo kraya (Cluster approach to the spatial development of tourist destinations in the region (on the example of Primorsky Territory), Ekonomicheskiye nauki 1(62), 143-147, (2010) http://ecsocman.hse.ru/data/ 2011/07/28/1267427146/28.pdf. Accessed 12 July 2020.

17. A.B. Kaczynski, Ekolohichna bezpeka Ukrayiny: systemnyy analiz perspektyv pokrashchennya (Ecological safety of Ukraine: a systematic analysis of prospects for improvement). (Kyiv, NICD, 2001).

18. S. Goshovsky, G. Rudko, B. Presner, Ekolohichna bezpeka tekhnopryrodnykh heosystem u zv"yazku z katastrofichnym rozvytkom heolohichnykh protsesiv (Ecological safety of techno-natural geosystems in connection with the catastrophic development of geological processes). (Kyiv, ZAT "NICHLAVA", 2002).

19. A.B. Kaczynski, T.A. Khmil, Ekolohichna bezpeka tekhnopryrodnykh heosystem $u$ zv"yazku $z$ katastrofichnym rozvytkom heolohichnykh protsesiv 
(Ecological security of Ukraine: analysis, assessment and state policy). (Kyiv, NICD, 1997).

20. V.O. Kosovtsev, I.F. Binko, Natsional'na bezpeka Ukrayiny: problemy ta shlyakhy realizatsiyi pryorytetnykh natsional'nykh interesiv (National security of Ukraine: problems and ways of realization of priority national interests). (Kyiv, NICD, 1996).

21. S.I. Doroguntsov, A.N. Ralchuk, Upravleniye tekhnogenno-yekologicheskoy bezopasnost'yu v kontekste paradigmy ustoychivogo razvitiya: kontseptsiya sistemno-dinamicheskogo resheniya (Managing technogenic and ecological safety in the context of the paradigm of sustainable development: the concept of a system-dynamic solution). (Kyiv, Naukova Dumka, 2002).

22. L. Shkitsa, T. Yatsyshyn, M. Lyakh, O. Sydorenko, Innovative approaches to the formation of environmental safety at the objects of oil and gas production. IOP Con f. Ser.: Mater. Sci. Eng. 749, 012009 (2020). doi:10.1088/1757-899X/749/1/ 012009 .

23. V.M. Shmandiy, Upravlinnya ekolohichnoyu bezpekoyu na rehional'nomu rivni(teoretychni ta praktychni aspekty) (Environmental safety management at the regional level (theoretical and practical aspects)), Abstract of the doctor of technical sciences (Kharkiv, 2004).

24. T. Yatsyshyn, L. Shkitsa, O. Popov, and M. Liakh, Development of Mathematical Models of Gas Leakage and Its Propagation in Atmospheric Air at an Emergency Gas Well Gushing, EEJET 5, 49-59 (2019). doi:10.15587/1729-4061.2019.179097.

25. V. Babak, V. Eremenko, and A. Zaporozhets, Research of diagnostic parameters of composite materials using Johnson distribution, IJC 18(4), 483494 (2019). Doi: 10.47839/ijc.18.4.1618.

26. M. L. Myrontsov. The method to research equivalent solutions zones for inverse problem of well logging electrometry, in Proceedings of the XIII International Scientific Conference "Monitoring of Geological Processes and Ecological Condition of the Environment", 2019, 1-5 (2019). doi:10.3997/22144609.201903217.

27. T. Yatsyshyn, N. Glibovytska, L. Skitsa, M. Liakh, S. Kachala, in Studies in Systems, Decision and Control Systems, ed. by V. Babak, V. Isaienko, A. Zaporozhets. Investigation of Biotechnogenic System Formed by Long-Term Impact of Oil Extraction Objects, (Springer, Cham, 2020). doi:10.1007/978-3030-48583-2_11.

28. N. Pobihun, Y. Korobeinykova, O. Pobihun, and I. Iuras, Ecological and Monitoring Studies of Oil Production Territories and Possibility of Their Use in Recreation, in Monitoring 2019 (European Association of Geoscientists \& Engineers, Kyiv, Ukraine, 2019), 1-5 (2019). doi:10.3997/2214-4609. 201903183.
29. A. Iatsyshyn, A. Iatsyshyn, V. Artemchuk, I. Kameneva, V. Kovach, and O. Popov, Software Tools for Tasks of Sustainable Development of Environmental Problems: Peculiarities of Programming and Implementation in the Specialists' Preparation, E3S Web Conf. 166, 01001 (2020). doi:10.1051/e3sconf/202016 601001 .

30. M. L. Myrontsov, Electrometry Effective Inverse Problem Solving Method, in Geoinformatics: Theoretical and Applied Aspects 2020 (European Association of $\mathrm{G}$ oscientists \& Engineers, Kyiv, Ukraine, 2020), 1-5. doi:10.3997/2214-4609.2020 geo090.

31. A. Zaporozhets, V. Babak, V. Isaienko, and K. Babikova, Analysis of the Air Pollution Monitoring System in Ukraine, in Systems, Decision and Control in Energy I, edited by V. Babak, V. Isaienko, and A. Zaporozhets, (Springer International Publishing, Cham, 2020). doi:10.1007/978-3-030-48583-2_6.

32. M.L. Myrontsov, A new method and program for multiprobe electric logging quantitative interpretation, in Proceedings of the 11th EAGE International Conference on Geoinformatics - Theoretical and Applied Aspects, May 2012.

33. A. Zaporozhets, Overview of Quadrocopters for Energy and Ecological Monitoring, in Systems, Decision and Control in Energy I, edited by V. Babak, V. Isaienko, and A. Zaporozhets, (Springer International Publishing, Cham, 2020). doi:10.1007/978-3-030-48583-2_2.

34. V.A. Kostyushin, Vozdeystviye rekreatsii na okruzhayushchuyu zhivuyu prirodu (The impact of recreation on the surrounding wildlife) (Natsional'nyy ekologicheskiy tsentr Ukrainy, Kyiv, 1997).

35. K.D. Nikolaev, VM Isaenko, KO Babinets, Zbalansovane pryrodokorystuvannya na prykladi ekolohizatsiyi turystychnoyi haluzi (Balanced nature management on the example of greening of the tourist industry), Bulletin of the Mykhailo Ostrogradsky 5(1), 117-120 (Kyiv State Pedagogical University, Kyiv, 2009).

36. M. Myrontsov. The method to solve the inverse problem of lateral logging sounding and lateral logging, in Monitoring 2019, 2019 (European Association of Geoscientists \& Engineers, Kyiv, Ukraine, 2019), 1-5. doi:10.3997/2214-4609. 201903244.

37. O. Savko, I. Melnychuk, I. Hobyr, and N. Havadzyn, Evaluation of the environmental taxation effectiveness in the field of oil and gas production. Procedia Environ. Sci. Eng. Manag. 6(4), 607-617 (2019). http://www.procedia-esem.eu/pdf/issues/ 2019/no4/69_Savko_19.pdf. Accessed 30 Nov 2020.

38. O.A. Vorobyova, Ekolohichna bezpeka yak skladova staloho rozvytku rekreatsiyno-turystychnykh terytoriy (Ecological safety as a warehouse for the development 
of recreational and tourist areas) in Proceedings of the III Vseukr. nauk.-prakt. konf "Stalyy rozvytok ta ekolohichna bezpeka suspil'stva v ekonomichnykh transformatsiyakh" Bakhchisarai, 15-16 september 2011 (Simferopol, Fenix, 2011), p. 46-48.

39. A.P. Holod, Z.P. Novosad, Ekolohichna bezpeka turyzmu $v$ rehioni: sut' ta shlyakhy zabezpechennya (Ecological safety of tourism in the region: essence and ways of providing) Scientific Bulletin of NLTU of Ukraine 22(3), 84-88 (Lviv, RVV NLTU of Ukraine, 2012).

40. N.V. Korzh, O.V. Zanosko, Formuvannya systemy ekonomichnoyi bezpeky industriyi turyzmu yak skladovoyi stiykoho rozvytku turyzmu $v$ Ukrayini (Formation of the system of economic security of the tourism industry as a component of sustainable tourism development in Ukraine). Ekonomika. Upravlinnya. Innovatsiyi. 2 (6) (Zhytomyr, 2011). http://nbuv.gov.ua/UJRN/eui_2011_2_24. Accessed 17 July 2019.

41. I.V. Kuchynska, Turyzm v umovakh hlobal'noyi ekolohichnoyi kryzy:suchasni vyklyky $i$ perspektyvy rozvytku (Tourism in the context of the global environmental crisis: current challenges and prospects for development) in Proceedings of the Mizhnarodnoyi naukovo-praktychnoyi konferentsiyi "Stratehiya rozvytku turyzmu u 21 st. u konteksti vyrishennya hlobal'nykh problem suchasnosti", Lviv, 28 may 2014 (Lviv, LIET, 2014), pp.291-301.

42. Resort "Bukovel", Official site. http://www.bukovel.com. Accessed 20 July 2020.

43. Energy Roadmap 2050. European Comission (2020). https://ec.europa.eu/energy/sites/ener/files/ documents/roadmap2050_ia_20120430_en_0.pdf. Accessed 17 Dec 2020.

44. O. Mandryk, N. Moskalchuk L. Arkhypova, M. Prykhodko, and O. Pobigun. Prospects of environmentally safe use of renewable energy sources in the sustainable tourism development of the Carpathian region of Ukraine. E3S Web Conf. 166, 04005 (2020). doi:10.1051/e3sconf/ 202016604005.

45. O. M. Mandryk, N. R. Moskalchuk, L. M. Arkhypova, M. M. Pryhodko, and O. V. Pobigun, Research quantitative indicators of the potential of solar energy in the Carpathian region of Ukraine. IOP Conf. Ser.: Mater. Sci. Eng. 749, 012033 (2020). doi:10.1088/1757-899X/749/1/012033.

46. O. M. Mandryk, L. M. Arkhypova, O. V. Pobigun, and O. R. Maniuk, Renewable Energy Sources for Sustainable Tourism in the Carpathian Region, IOP Conf. Ser.: Mater. Sci. Eng. 144, 012007 (2016). doi: 10.1088/1757-899X/144/1/012007.

47. A.O. Zaporozhets, Methods and Means for the Control of the Fuel Combustion, in Studies in Systems, Decision and Control Systems, Springer, Cham, 287, 1-33 (2020). doi:10.1007/978-3-030-46299-4_1.
48. A. Iatsyshyn, A. Iatsyshyn, V. Kovach, I. Zinovieva, V. Artemchuk, O. Popov, O. Cholyshkina, O. Radchenko, O. Radchenko, A. Turevych. Application of Open and Specialized Geoinformation Systems for Computer Modelling Studying by Students and $\mathrm{PhD}$ Students, in CEUR Workshop Proceedings, vol. 2732, (2020), pp.893-908, http://ceur-ws.org/Vol2732/20200893.pdf. Accessed 25 Nov 2020.

49. V. Gurieiev, Yu. Kutsan, A. Iatsyshyn, A. Iatsyshyn, V. Kovach, E. Lysenko, V. Artemchuk, O. Popov, Simulating Systems for Advanced Training and Professional Development of Energy Specialists in Power Sector, in CEUR Workshop Proceedings, vol. 2732, (2020), pp. 693-708. http://ceur-ws.org/Vol2732/20200693.pdf Accessed 25 Nov 2020.

50. L. Shkitsa, T. Yatsyshyn, M. Lyakh, and O. Sydorenko, Means of atmospheric air pollution reduction during drilling wells. IOP Conf. Ser.: Mater. Sci. Eng. 144, 012009 (2016). doi:10.1088/1757899X/144/1/012009.

51. O. Popov, A. Iatsyshyn, V. Kovach, V. Artemchuk, I. Kameneva, D. Taraduda, V. Sobyna, D. Sokolov, M. Dement, and T. Yatsyshyn, Risk Assessment for the Population of Kyiv, Ukraine as a Result of Atmospheric Air Pollution, Journal of Health and Pollution 10, 200303 (2020). doi:10.5696/2156-961410.25 .

52. I. Murava and Y. Korobeinykova, The analysis of the waste problem in tourist destinations on the example of carpathian region in ukraine, J. Ecol. Eng. 17, 43-51 (2016). doi:10.12911/22998993/62285.

53. Y.S. Korobeynikova, I.I. Iuras, Modelyuvannya obsyahiv utvorennya tverdykh pobutovykh vidkhodiv $v$ turystychnykh destynatsiyakh (Modeling the volume of solid waste generation in tourist destinations), Ekolohichna bezpeka ta zbalansovane resursokorystuvannya 1(15), 129-133 (IvanoFrankivsk, 2017).

54. I. Iuras, P. Raiter, Y. Korobeinykova, and L. Poberezhna, Methodology of Actors Analysis and Modeling of the Amounts of Solid Municipal Waste Generation within Tourist Destinations. EQ. 31(2), 6369 (2020). doi: 10.12775/EQ.2020.014.

55. S. Kis, L. Mosora, Y. Mosora, O. Yatsiuk, G. Malynovska, S. Pobihun. Personnel Certification as a Necessary Condition for Enterprise' Staff Development, Management Systems in Production Engineering 28(2), 121-126 (2020). doi:10.2478/mspe-2020-0018. 